\title{
The Quality Test of Fermented Ginger Drink (Ginger Ale) Produced from Various Types of Indonesian Ginger
}

\author{
Pujiati $^{1}$, Ani Sulistyarsi ${ }^{2}$, Nur Fajri Prafitasari ${ }^{3}$ \\ 1,2,3 Biology Education Department, Faculty of Teaching and Education Learning, Universitas PGRI Madiun, \\ Indonesia \\ "Corresponding author.Email: pujiati@unipma.ac.id
}

\begin{abstract}
The pandemic due to the spread of COVID 19 is a worldwide problem. Many attempts to increase immunity were made. Consuming spices and herbs is proven to increase immunity and nourish the body. A spice that is often used and very popular during the COVID 19 pandemic is ginger. This study aims to determine the probiotic bacteria and phenolic compounds contained in fermented ginger drink known as " Ginger Beer ", and organzoleptic tests to determine the taste of several types of ginger in Indonesia, namely "Jahe Gajah/elephant ginger (Z. officinale var. officinarum), Jahe Emprit/emprit ginger (Z. officinale var. amarum) And Jahe Merah/Red Ginger (Z. officinale var. rubrum) ". The experimental method for this research was the organoleptic test, isolation of the probiotic microorganism, measurement of alcohol level, reducing sugar, and identification of phenolic compounds. The results showed that there were probiotic bacteria in ginger ale, from the Lactobacillus, Streptococcus and Micrococcus genus. Organoleptic test results by panelists showed that ginger ale from ginger emprit has a good taste. In addition, it is found to contain a phenolic compound (flavonoid group), namely luteolin. The highest reducing sugar content and alcohol content was ginger ale produced from "Jahe Emprit" with a value of $9.78 \%$ and $14.8 \%$. and ginger ale from "Ginger elephant" showed the lowest reducing sugar and alcohol content of $3.65 \%$ and $11.04 \% 7$ and $14.8 \%$.
\end{abstract}

Keywords: Ginger, ginger ale, Indonesia, probiotics, flavonoids.

\section{INTRODUCTION}

The pandemic situation caused by the spread of the COVID-19 virus makes most people very careful in all their activities. To combat the spread and transmission of Covid-19 in Indonesia, the government has established rules and health standards. Furthermore, the government encourages the population to preserve their health and immunity. People are also urged to take spices that have been shown to boost immunity and nourish the body in addition to these efforts. Spices like ginger, turmeric, temulawak, and others are processed into functional meals that are good for the body and improve immunity due to the antioxidant content present in spices.

Indonesians are known to frequently employ herbal plants, such as ginger plants, to prepare food or drinks. Ginger (Zingiber Officinale) is a ginger family that is commonly used to produce ginger beverages. Ginger is a biopharmaceutical plant with fat, protein, starch, water fiber, ash, volatile oil, and resinous materials. There are three types of ginger in Indonesia, including emprit ginger (Z. officinale var. amarum), elephant ginger $(Z$. officinale var. officinarum) and red ginger (Z. officinale var. rubrum). Red ginger is generally utilized for dietary enhancement or homegrown prescriptions, while elephant and emprit ginger are typically utilized for cooking flavors or herbal drinks. Nowadays, there is encouraging data regarding the health-promoting benefits of ginger, which is being consumed in an increasing number of countries. Ginger is commonly found in large quantities in Asian culinary items. Nowadays, there is encouraging data regarding the health-promoting benefits of ginger, which is being consumed in an increasing number of countries. Ginger is commonly found in large quantities in Asian culinary items. For centuries, ginger has been used in traditional and folk medical systems in Asia, including Indonesia, to cure a variety of ailments such as headaches, colds, 
osteoarthritis, muscular pains, neurological diseases, gingivitis, toothaches, and asthma. Today, much study is being conducted on different aspects of ginger's activity. Phytochemicals in ginger, such as 6-gingerol (6G), 8gingerol (8G), 10-gingerol, and 6-shogaol (6S), have been identified as the major bioactive components ([1]). It includes natural bioactive components that serve as an antiemetic, cancer preventative, antipyretic, antioxidant, and anti-inflammatory, immunological modulatory, anticarcinogenic, immunological modulatory, antibacterial, antifungal, anti-hyperglycemic, and antiatherosclerotic[2], [3]

In addition to beverages, ginger is frequently used in cooking to enhance the flavor. All foods and drinks produced with ginger are beneficial to health[4]. Beverage goods are one of the food items that are currently being produced. Innovative ginger-based technology is beginning to develop, with the Ginger Ale fermented beverage serving as an example.

Ginger Ale is a fermented drink made with grated ginger, sugar, water, and lemon juice that has been fermented to get the desired flavor. Fermentation can be defined as a biological process in which microorganisms convert substrates into new products. Fermentation is a biological conversion method used by microbes to break down complex substrates into simpler components. Potential microorganisms are added during the fermentation process to improve product quality[5][6]. Food fermentation dates back to many centuries ago and is considered a food preserving technique, a way of obtaining traditional and nutritive foods, and also a tool for obtaining new flavours, aromas, and textures that foster gastronomic pleasure [7], [8]. The general public is still unfamiliar with Ginger Ale since conclusive data on the production method, standard formula, biochemical changes, the type of bacteria employed, and the content contained in it has yet to be discovered. The purpose of this study is to assess the alcohol level, phenolic compounds, reducing sugars, and organoleptic assessment as well as the quality of Ginger Ale made from several varieties of ginger bugs.

\section{METHODS}

This is an experimental study that comprises organoleptic testing for the quality of Ginger Ale probiotic drink, gram staining for microbial identification, alcohol level calculation, sugar reduction, and determining the presence or absence of phenolic chemicals. Ginger samples were obtained at the Madiun local market (Market Dolopo). The research was conducted at the Biology Education Laboratory of Universitas PGRI Madiun.

\subsection{Tools and Material}

During the research, the following tools were used: beakers, erlenmeyer, test tubes and racks, electric stove, digital scales, stirrer, staining gram set, ose, Bunsen, yellow tip, volume pipette, mortar and pestle, petri dish, aluminum foil, cling warp, label paper, micropipette, autoclave, measuring cup, clamp, binocular microscope, object glass, paper cup Grated ginger, water and sugar, lemon juice, NA agar medium and skim milk, griseovulvin, aquades, Ginger Ale, 70\% alcohol, alcohol, distilled water, acetone, ice, cork, boiling stone, luff solution were the study materials utilize, amylum $1 \%$, $\mathrm{KLO}_{3} 0,1 \mathrm{~N}, \mathrm{KL} 20 \%, \mathrm{H}_{2} \mathrm{SO}_{4} 25 \%, \mathrm{NA}_{2} \mathrm{C}_{2} \mathrm{O}_{2} 0,1 \mathrm{~N}$, $\mathrm{H}_{2} \mathrm{SO}_{2} 4 \mathrm{~N}$, NAOH $30 \%$.

\subsection{Procedures for conducting research}

\subsubsection{Preparing Ginger Bugs}

Ginger bug is a probiotic starter used in the production of ginger ale. Ginger Bug is produced by extracting 22 grams of ginger including red ginger, emprit ginger, elephant ginger and then diluting it in 500 cc of water with 28 grams of sugar. Allow the solution to ferment for 4 days after homogenizing it. The ginger bug production formula is as follows:[9]

Table 1. Ginger Bug production formula

\begin{tabular}{lll}
\hline No & Amount & Ingredients \\
\hline 1. & $500 \mathrm{ml}$ & Water \\
\hline 2. & $22 \mathrm{gr}$ & Ginger \\
\hline 3. & $28 \mathrm{gr}$ & Sugar \\
\hline
\end{tabular}

\subsubsection{Ginger Ale Making}

Ginger ale is made by making ginger tea which is added by using ginger bug as a result of the fermentation process. The composition of ginger ale is described in table 2 .

Ginger tea is made by boiling 22 grams of grated ginger in $500 \mathrm{ml}$ of water. After boiling, it was then cooled to a temperature of about $30^{\circ} \mathrm{C}$. After cooling, 90 $\mathrm{ml}$ of lemon juice and ginger bug were added as a probiotic starter. Finally, the ginger ale solution was incubated for 7 days at room temperature. Check by opening the lid to reduce the pressure of the gas formed [10]:

Table 2: Ginger Ale Formula

\begin{tabular}{c|c}
\hline Water & $500 \mathrm{ml}$ \\
\hline Ginger bug & $100 \mathrm{ml}$ \\
\hline Lemon Juice & $90 \mathrm{ml}$ \\
\hline Grated Ginger & $22 \mathrm{gr}$ \\
\hline Sugar & $28 \mathrm{gr}$ \\
\hline
\end{tabular}


The formula is used to make ginger ale from 3 types of local ginger in Indonesia, including red ginger, emprit ginger, elephant ginger

\subsubsection{Isolation of Probiotic Bacteria from Ginger Ale}

\subsubsection{Isolating probiotic microorganisms using selective media}

The simple selective medium used for the isolation of probiotic bacteria was Nutrien Agar which was added with skim implants. NA medium is a general medium that has nutrients for the growth of heterotrophic microbes[11][12]. In the process of making the media, it begins by weighing 5.4 grams of NA and putting it in 270 $\mathrm{ml}$ of distilled water and adding $10 \%$ ( 27 grams) of skim milk. Heat the media, then sterilize by autoclaving for 15 minutes at $121^{\circ} \mathrm{C}$. The next step is to mix the solution until it is homogeneous. After the temperature drops, the solution is put into a petri dish which already contains a sample of Ginger Ale dilution and Griseovulvin is added as an anti-mold. Let it solidify and be ready to store until the bacteria grow.

\subsubsection{Identification of probiotic microbes.}

After the process of making the media, the next step is to isolate the microbes to be identified from Ginger Ale. Isolation was done by preparing a test tube filled with $9 \mathrm{ml}$ of distilled water. Then enter the sample as much as possible into the test tube 1 to 10 using a micropipette that has been cleaned with alcohol spray. After that, take samples at the 6th, 8th and 10th dilutions and put $1 \mathrm{ml}$ into a petri dish and add a solution of media and griseovulvin. Close the petri dish using a cling warp and homogenize it by rotating it. Leave it to solidify. During the sampling process and the homogeneity process, place the pipette near the fire so that it is not contaminated with other bacteria. Gram staining is carried out on bacteria aged $1 \times 24$ hours, $3 \times 24$ hours, $5 \times 24$ hours and $7 \times 24$ hours using the gram color set. The final result for gram positive is purple and gram negative is red.

\subsubsection{Alcohol distillation}

Take $25 \mathrm{ml}$ of alcohol using a volume pipette and enter it into a distillate flask. Enter the distillate flask with $25 \mathrm{ml}$ of aquadest using a volume pipette as well. Perform the distillation process and the results of the distillate are accommodated in an erlenmeyer. Heating is carried out at a temperature of $80^{\circ} \mathrm{C}-90^{\circ} \mathrm{C}$. If in the Erlenmeyer, approximately $25 \mathrm{~mL}$ is collected, the distillation process is stopped. The distillate is cooled. Put the distillate into the pycnometer. Previously, the pycnometer and watch glass were rinsed with acetone, then heated in an oven and cooled in a desiccator, weighed. A pycnometer containing alcohol is cooled on ice to a temperature of approximately 180C. Remove and wipe the pycnometer using a tissue and wait until the temperature is $200 \mathrm{C}$, then weigh. Rinse the pycnometer with acetone, put it in the oven, and insert a desiccator. Fill the pycnometer with distilled water. Cool with ice to a temperature of approximately $180 \mathrm{C}$. Remove and wipe the pycnometer with a tissue and wait until the temperature is $200 \mathrm{C}$, then weigh. Calculate the specific gravity of alcohol.

\subsubsection{Determination of reducing sugar}

Analysis of changes in reducing sugar content in the substrate using the Luff School method. Every 24 hours, 5 grams of substrate are removed from the bottle and mixed with $50 \mathrm{~mL}$ of distilled water. The suspension was centrifuged at $4000 \mathrm{rpm}$ for 20 minutes, and the supernatant was used to test reducing sugar levels. Pipette $10 \mathrm{~mL}$ of the supernatant into the flask boil then pour 10 $\mathrm{mL}$ of Luff's reagent School. After boiling at reflux for 10 minutes, $6 \mathrm{~mL}$ of $\mathrm{KI} 20 \%$ and $10 \mathrm{~mL}$ of $\mathrm{H}_{2} \mathrm{SO}_{4}$ were carefully added through the flask walls. Titrate the sample with $0.1 \mathrm{~N} \mathrm{Na}_{2} \mathrm{~S}_{2} \mathrm{O}_{3}$ to a yellow color, then add $1 \%$ starch titration. Continue until the blue color disappears. Make a blank titration using water instead of the sample. The reducing sugar content is calculated by the formula[6]:

$$
\text { reducing sugar (\%) } \frac{A T \times F p}{\text { Weight of sample } x 1000} \times 100 \%
$$

Notes: AT: The Luff Shoorls table number. Fp: The dilution factor.

\subsubsection{Phenol Compound determination by TLC}

Thin layer chromatography (TLC) was used to assess the qualitative concentration of phytocomponents such as phenolic content, tannins, and flavonoids[13]. The filtrate was evaporated to $1 / 10$ of the volume at $40 \mathrm{oC}$. Hydrolyzed in an acid atmosphere with $\mathrm{H}_{2} \mathrm{SO}_{4} 2 \mathrm{M} / \mathrm{HCL}$ $2 \mathrm{M}$ for an hour, then cooled and filtered before extraction. The extraction result was evaporated to dryness before adding a small amount of CHCL-3 ether to make the filtrate wet. Fill the camber with BAA expansion solution (butanol, acetic acid, water). 4:1:5 can be used for acetic acid, CHCL-3, and acetyl acetatebenzene. Put the filter paper in a position around the entire inner chamber wall. Line the upper and lower sides of the TLC plate $1 \mathrm{~cm}$ each. Put a pen in the form of a capillary tube into the filtrate and then put it on the TLC plate at the bottom line. Insert the TLC plate into the chamber, When the developer solution is saturated, it is indicated by the wetness of the entire filter paper. When the TLC plate has been inserted, close the chamber, take the TLC plate when the eluent has reached the upper line/limit (do not exceed the upper limit line). Check the 
stain on the TLC paper with a UV lamp, if the stain means the filtrate contains phenol.

\subsubsection{Organoleptic Test}

This test involves 3 experienced panelists and 12 general panelists who will assess the research sample and fill in the results of the assessment into the questionnaire that has been provided. Assessment includes the aroma, color, taste, and texture of the sample. The organoleptic testing was performed by assessing ginger Ale quality based on the value scale from 1 to $5[14]$.

\section{RESULT}

Microbial identification data from the Universitas PGRI Madiun laboratory revealed three types of bacteria: coccus, or round-shaped bacteria, such as Streptococcus, and Micrococcus., the last one is bacillus, or rod-shaped bacteria, such as Lactobacillus. The results of the study data on the identification of microorganisms in fermented ginger ale drinks are shown in Figure 1, Figure 2 and Table 3, which presents the results of chemical tests.

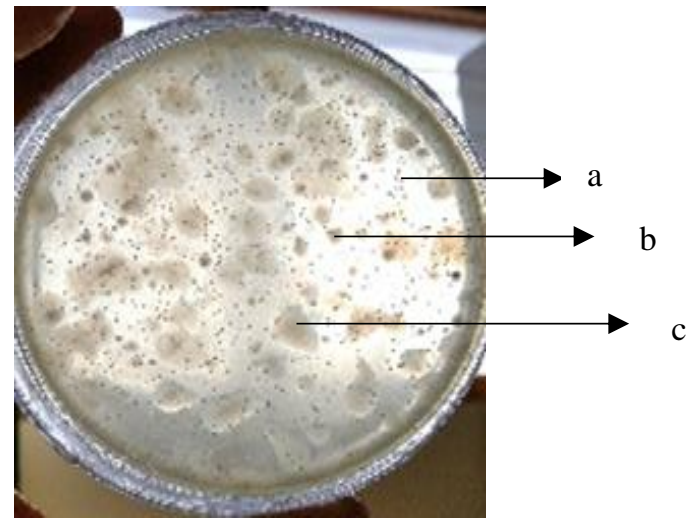

Figure 1. Macroscopic picture of bacteria on nutrient agar + skim milk medium (a. Micrococcus, b. Streptococcus, c. Lactobacillus)
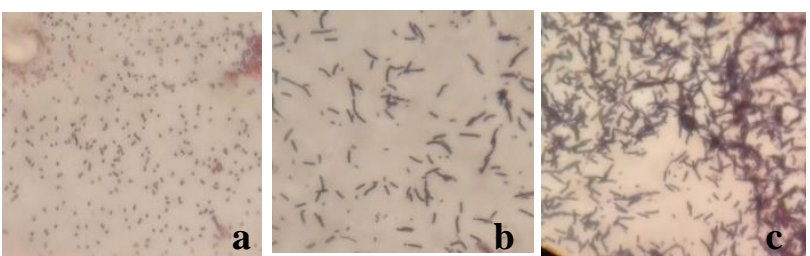

Figure 2. Staining gram results (a. Micrococcus, b. Streptococcus, c. Lactobacillus)
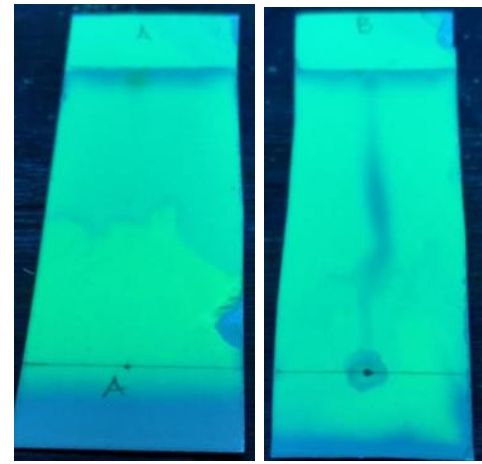

Figure 3. Phenolic test using Thin Layer Chromatography (TLC) method

Phenolic compounds were found in ginger ale samples including 3 types of ginger. The phenolic compound namely + Flavone (Luteolin) group. With a price of $\mathrm{Rf}$ $78 \mathrm{~mm}$ with a yellowish green color.

Table 3. Reducing sugar and alcohol level of ginger ale from various local ginger in Indonesia

\begin{tabular}{c|l|l|l|c|}
\hline $\begin{array}{l}\mathbf{N} \\
\mathbf{0}\end{array}$ & Ginger ale formula & $\begin{array}{l}\text { Reducing } \\
\text { Sugar }(\boldsymbol{\%})\end{array}$ & $\begin{array}{l}\text { Alcohol } \\
\text { level } \\
(\boldsymbol{\%})\end{array}$ & $\begin{array}{l}\mathbf{p H} \\
\mathbf{2 4 h r s}\end{array}$ \\
\hline 1 & $\begin{array}{l}\text { Emprit ginger } \\
\text { Z. officinale var. amarum }\end{array}$ & 9,78 & 14,8 & 3 \\
\hline 2 & $\begin{array}{l}\text { Elephant Ginger } \\
\text { Z. officinale var. } \\
\text { officinarum }\end{array}$ & 3,65 & 11,04 & 3 \\
\hline 3 & $\begin{array}{l}\text { Red Ginger } \\
\text { Z. officinale var. rubrum }\end{array}$ & 6.34 & 12,31 & 4 \\
\cline { 2 - 5 } & & & & \\
\cline { 2 - 5 }
\end{tabular}

For the sample of Elephant ginger ale reducing sugar obtained as much as $3.65 \%$. And for the sample emprit ginger ale reducing sugar obtained $9.78 \%$.

For the Elephant ginger ale sample, the alcohol content obtained was $11.04 \%$. And for emprit ginger ale reducing sugar obtained was $14.8 \%$.

The results of the analysis of organoleptic test data obtained samples of ginger ale from emprit ginger as drinks that were mostly chosen by the panelists. Of the total 15 panelists, there were 3 expert panelists and 12 general panelists. 2 expert panelists chose the emprit ginger formula with the addition of 40 grams of sugar and 1 expert panelist chose the emprit ginger formula with the addition of 35 grams of sugar. The general panelists who chose the emprit ginger ale with the addition of 35 grams of sugar were 4 people, while the emprit ginger formula with the addition of 40 grams of sugar was 6 people. The remaining 2 general panelists chose the elephant ginger formula with the addition of 35 grams of sugar.

\section{DISCUSSION}

As previously explained, the purpose of this research is to produce fermented beverages from ginger extract. Ginger ale production uses 3 Indonesian local gingers. These three ginger cultivars have varying levels of 
pungency due to the varied amounts of certain homologous phenolic ketones, notably 6-, 8-, 10gingerol, and 6-shogaol, which have been identified as the main pungent chemicals in ginger[15]. Disparities in the quantity of these pungent chemicals may be attributed to phenotypic diversity, harvesting, and postharvest procedures (e.g. washing, drying, crushing, pulverizing) and nutrient availability.

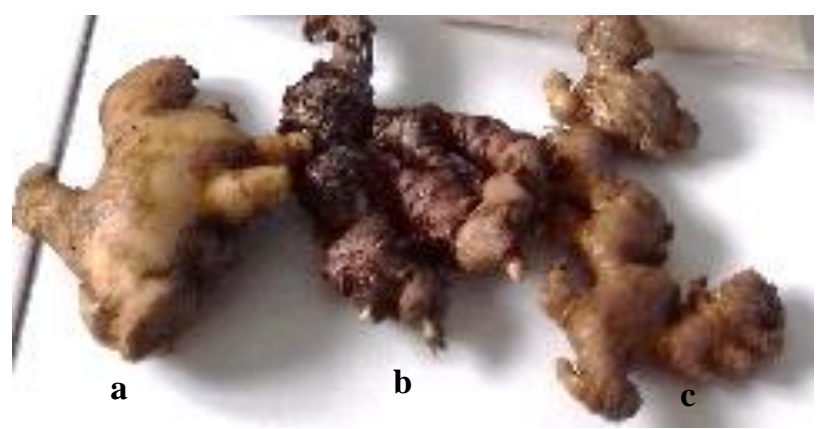

Figure 4. Indonesian local gingers: a. Elephant ginger; b. Red ginger; c. Empritginger

\subsection{Ginger Ale's probiotic microorganisms}

The goal of microbiome description is to determine the properties of microorganisms both macroscopically and microscopically[16]. According to laboratory research, three types of LAB were discovered, namely Lactobacillus Streptococcus, and micrococcus that observed using gram staining, macroscopic and microscopic identification.

According to the US Food and Drug Administration, the great majority of LAB are 'Generally Recognized As Safe' (GRAS) (FDA). The European Food Safety Authority (EFSA) has also granted many LAB species the status of "Qualified Presumption of Safety" (QPS), including those in the genera Carnobacterium, Lactococcus, Leuconostoc, Oenococcus, Pediococcus, Streptococcus, and the former Lactobacillus genus, which was recently reclassified into twenty-five new genera [17][18]

Gram staining is an essential method for distinguishing between gram-positive and gram-negative microorganisms. The idea is to stain germs using Crystal violet and safranin.

Gram-positive bacteria absorb crystal violet, but gram-negative bacteria absorb safranin, causing it to become red. discovered that gram-positive bacteria have thick peptidoglycan walls in his study. A thick peptidoglycan produced by Gram-positive bacteria is regarded invariable, and the surface glycol-polymers on these bacteria's surfaces can be different. Gram-negative bacteria, on the other hand, do have an outer membrane[19][20]. As a result, gram-positive bacteria can tolerate crystal violet, which creates the purple color. Because gram-negative bacteria have three layers of cell walls, alcohol will wash away the lipids as well as the violet stain. When Gram-negative bacteria are stained with safranin, they become red. The results of the tests revealed that there were three purple bacteria that were gram-positive bacteria, round and rod-shaped, and thought to be lactic acid bacteria. LAB are gram-positive bacteria that have a purple color when stained with bacteria, are coccus and bacillus, do not have spores, can ferment carbohydrates, are catalase negative, and belong to the microphilic bacteria group. LABs are found in the natural microbiota of fermented foods as well as in the human gut microbiome. They have traditionally been widely used in fermentation processes, converting carbohydrates to lactic acid and producing other physiologically active chemicals such as organic acids, diacetyl, acetoin, polyols, hydrogen peroxide, antifungal and antibacterial peptides, and taste precursors [21], [22].

The presence of probiotic bacteria in the Ginger Ale sample was discovered using a 40x magnification. Based on their descriptions and features, both were recognized as probiotic bacteria. Both have gram-positive features, and the color of both is purple as a result of bacterial staining. Lactobacillus bacteria are rod-shaped, grampositive bacteria that form chains. Lactobacillus was discovered at $10^{-6}$ dilution in NA+ skimmed milk medium. The streptococcus bacterium has a round shape, some creates a long round chain, and is round in shape alone, with a purple gram that identifies it as a grampositive bacteria group. Micrococcus is Gram-positive nonmotile coccoid bacteria. Probiotic bacteria were discovered in red ginger, elephant ginger, and emprit ginger samples. Lactic acid bacteria growth may also be accelerated by increasing incubation time, temperature, humidity, light, $\mathrm{pH}$, and nutrients, resulting in more optimal lactic acid bacteria growth[23][24]

\subsection{Data on the organoleptic properties of Ginger Ale}

Based on a questionnaire issued to professional and general panelist regarding organoleptic testing on the Ginger ale probiotic drink. The panelists enjoyed the drink's taste, which was sweet, sour, fizzy, and gingerflavored, making the Ginger Ale drink in the sample with a formula of 35 grams of added sugar as formula 2 and 40 grams of added sugar as formula 3 the favorite. The elephant variety was not chosen since the ginger flavor is less strong and tends to be more acidic. When it came to red ginger, the panelists agreed that the flavor was excessively hot and tended to be bitter. In addition to the taste of emprit ginger, the panelists like the scent of fermented Ginger ale emprit because it feels fresh and retains the aroma of ginger, which is an appeal in and of itself. According to the judges, the general mouthfeel of the Ginger ale drink is effervescent, watery, and includes sediment. Each drink creates a distinct hue in terms of color. Red ginger has a hazy pink hue, elephant ginger 
has a cloudy yellow color, and emprit ginger has a white and somewhat clear appearance.

\subsection{Phenolic compounds}

The findings of the content research Ginger Ale was used to identify phenolic chemicals, and both were positive for flavone (Luteolin) phenolic compounds with $\mathrm{Rf} 78 \mathrm{~mm}$ pricing (yellowish green color). Luteolin is an antioxidant, anti-inflammatory, apoptosis-inducing, and chemopreventive. Luteolin has anti-tumor action, which slows cell proliferation, injects DNA toposimerase II activity, and delays the process of cancer cell formation. Luteolin, a naturally found dietary flavonoid, has a wide range of beneficial biological effects. Studies proved that luteolin can modulate immune responses, antiinflammatory[25][26]. Red ginger and emprit have higher essential oil concentration than elephant ginger, at $2.5 \%, 2.5 \%$, and $2.5 \%$ respectively[27]. Differences in the concentration of bioactive components may also influence the biological activity elicited by each ginger.

\subsection{Sugar content reduction}

The reducing sugar concentration is calculated using an iodometric technique in which monosaccharides are oxidized by $\mathrm{CuO}$ and Luff Schoorl's reagent. The laboratory results reveal that the sugar level in Ginger Ale is 3.65 percent for elephant ginger and 9.78 percent for sample emprit ginger ale.

The reducing sugar test was performed to assess the amount of sugar that remained after the fermentation process[28]. The time of fermentation has an influence on the amount of reducing sugar needed for microbial development throughout the fermentation process, the longer the fermentation, the more reducing sugar is used for microbial growth. Lactic acid bacteria will consume reduced sugars as a carbon source for microbial metabolic activity. Sugar reduction occurs as a result of carbohydrate metabolism, which is utilized by bacteria for growth and metabolite synthesis. At the end of fermentation, a drop in decreasing sugar levels suggests the production of secondary metabolites.

\subsection{Alcohol level}

Measurement of alcohol content was carried out to determine the level of alcohol in ginger ale produced in 3 types of Indonesian ginger. Alcohol and carbon dioxide are produced during the fermentation process, as well as additional compounds like acetic acid[29]. Alcohol (ethanol) generation during the fermentation of sugarbased beverages may be an issue for non-alcoholic beverages, and their impact on blood alcohol level has been called into doubt in a court case[30]. The distillation process is used to calculate the alcohol concentration. After being tested in the laboratory to determine the amount of alcohol content in Ginger Ale, the findings showed that the alcohol content for elephant was 11.04 percent and the alcohol content for the emprit ginger ale was 14.8 percent.

According to Indonesian Presidential Decree No. 1 of 1997 concerning the supervision and trial of Ginger Ale drinks, which the author has made, it is classified as group $\mathrm{B}$, which means that it is included in the group of alcoholic beverages whose production, distribution, and sales are controlled goods.

\section{CONCLUSIONS}

Ginger Ale fermented drink were confirmed to contain probiotic bacteria including Lactobacillus, Streptococcus and Micrococcus. According to the results of the organoleptic test questionnaire, the panelists favored the Ginger Ale recipe from ginger emprit variations. Because it was thought to have the proper flavor. Laboratory testing revealed the presence of flavone phenolic chemicals, specifically luteolin, which is an antioxidant. The levels of decreasing sugar generated by ginger ale are 3.65 percent and 9.78 percent. Alcolohol level from 3 types of Indonesian ginger are $14,8 \%$ (emprit ginger), 11,04 (elephant ginger) and 12,31(red ginger). Further study on organoleptic testing of Ginger Ale is required in order to develop Ginger Ale beverages that can be enjoyed by the general population, ranging from toddlers to adults, and that can be utilized as a beverage company with raw materials derived from local ginger plants. More study is needed to learn more about the contents of the Ginger Ale probiotic drink, independent of the alcohol concentration, the presence or lack of phenolic compounds, or the presence or absence of lowering sugar levels. More study on the elements that impact the content of Ginger Ale is required before it can be employed as a small-scale or large-scale industry.

\section{AUTHORS’ CONTRIBUTIONS}

Pujiati: Conceptualization, data analysis, writingoriginal draft, Writing - review \& editing validation, Resources, Supervision. Ani Sulistyarsi: review original draft, formal analysis, Investigation, Validation, Formal analysis, Resources. Nur Fajri Prafitasari: Data curation, Methodology, Formal analysis, Visualization

\section{ACKNOWLEDGMENTS}

The authors acknowledge Universitas PGRI Madiun for providing the research facilities.

\section{REFERENCES}

[1] M. Ogino et al., "Enhanced pharmacokinetic behavior and hepatoprotective function of ginger extract-loaded supersaturable self-emulsifying drug delivery systems," J. Funct. Foods, vol. 40, pp. 156163, 2018, doi: 10.1016/j.jff.2017.08.035. 
[2] H. Li et al., "Ginger for health care: An overview of systematic reviews," Complement. Ther. Med., vol. 45, pp. 114-123, 2019, doi: 10.1016/j.ctim.2019.06.002.

[3] P. Sarkaya, E. Akan, and O. Kinik, "Use of kombucha culture in the production of fermented dairy beverages," Lwt, vol. 137, p. 110326, 2021, doi: 10.1016/j.lwt.2020.110326.

[4] M. Astawan, Sehat dengan rempah dan bumbu dapur, vol. 18, no. 2. Indonesia: Penerbit Buku Kompas, 2016.

[5] Pujiati, M. W. Ardhi, and A. Sulistyarsi, "ANALISA KADAR PROTEIN CRUDE ENZIM SELULASE DARI KAPANG Rhizopuz Sp PADA SUBSTRAT AMPAS TEBU HASIL ISOLASI DARI KEBUN CENGKEH, KARE, MADIUN," Biota, vol. 3, no. 1, p. 26, 2017, doi: 10.19109/biota.v3i1.930.

[6] Pujiati and C. N. Primiani, "Analisis Kadar Gula Reduksi pada Fermentasi Kacang Gude (Cajanus cajan) oleh Aspergillus niger," vol. 13, no. 1, pp. 832-835, 2016, [Online]. Available: https://jurnal.uns.ac.id/prosbi/article/view/5930/53 16.

[7] S. Garrido-Galand, A. Asensio-Grau, J. CalvoLerma, A. Heredia, and A. Andrés, "The potential of fermentation on nutritional and technological improvement of cereal and legume flours: A review," Food Res. Int., vol. 145, no. May, 2021, doi: 10.1016/j.foodres.2021.110398.

[8] C. N. Primiani, Pujiati, M. Mumtahanah, and W. Ardhi, "Kombucha fermentation test used for various types of herbal teas," J. Phys. Conf. Ser., vol. 1025, no. 1, 2018, doi: 10.1088/1742$6596 / 1025 / 1 / 012073$.

[9] J. Mueller, Delicious Probiotic Drinks, vol. 2. Skyhorse, 2014.

[10] J. Morgenthaler, M. Holmberg, and A. Hale, The bar book: elements of cocktail technique. USA: Chronicle Books, 2014.

[11] M. W. Ardhi, A. Sulistyarsi, and Pujiati, "The production and activity test of cellulases using bagasse substrate on Aspergillus Niger isolated from Clove field, Kare, Madiun," AIP Conf. Proc., vol. 1854, no. June, 2017, doi: 10.1063/1.4985393.

[12] Pujiati, "Isolasi actinomycetes dari tanah kebun sebagai bahan petunjuk praktikum mikrobiologi," vol. 1, no. 2, pp. 42-46, 2014.

[13] S. K. Dinakaran, S. Chelle, and H. Avasarala, "Profiling and determination of phenolic compounds in poly herbal formulations and their comparative evaluation," J. Tradit. Complement. Med., vol. 9, no. 4, pp. 319-327, 2019, doi: 10.1016/j.jtcme.2017.12.001.

[14] E. Surya et al., "The utilization of peanut sprout extract as a green nitrogen source for the physicochemical and organoleptic properties of Nata de coco," Biocatal. Agric. Biotechnol., vol. 29, no. August, p. 101781, 2020, doi: 10.1016/j.bcab.2020.101781.

[15] M. Rafi, L. W. Lim, T. Takeuchi, and L. K. Darusman, "Simultaneous determination of gingerols and shogaol using capillary liquid chromatography and its application in discrimination of three ginger varieties from Indonesia," Talanta, vol. 103, pp. 28-32, 2013, doi: 10.1016/j.talanta.2012.09.057.

[16] Pujiati, M. W. Ardhi, and A. Sulistyarsi, "ISOLATION OF CELLULOLYTIC MOLD FROM SOIL OF TEAK FOREST IN KRESEK, MADIUN," Proceeding Int. Conf. 2013 , 4th Green Technol. Fac. Sci. Technol. Islam. Univ. State Maulana Malik Ibrahim Malang, p. 23, 2013, [Online]. Available: http://repository.unas.ac.id/252/1/B19-ProsidingGreen Tech Conference.pdf\#page $=29$.

[17] J. Zheng et al., "A taxonomic note on the genus Lactobacillus: Description of 23 novel genera, emended description of the genus Lactobacillus beijerinck 1901, and union of Lactobacillaceae and Leuconostocaceae," Int. J. Syst. Evol. Microbiol., vol. 70, no. 4, pp. 2782-2858, 2020, doi: 10.1099/ijsem.0.004107.

[18] U. Nwachukwu, U. George-Okafor, U. Ozoani, and N. Ojiagu, "Assessment of probiotic potentials of Lactobacillus plantarum CS and Micrococcus luteus CS from fermented milled corn-soybean wastemeal," Sci. African, vol. 6, 2019, doi: 10.1016/j.sciaf.2019.e00183.

[19] R. Ruhal and R. Kataria, "Biofilm patterns in grampositive and gram-negative bacteria," Microbiol. Res., vol. 251, no. March, p. 126829, 2021, doi: 10.1016/j.micres.2021.126829.

[20] W. Y. Huang, M. S. Lee, L. M. Lin, and Y. C. Liu, "Diagnostic performance of the Sputum Gram Stain in predicting sputum culture results for critically ill pediatric patients with pneumonia," Pediatr. Neonatol., vol. 61, no. 4, pp. 420-425, 2020, doi: 10.1016/j.pedneo.2020.03.014.

[21] K. Egan, D. Field, M. C. Rea, R. P. Ross, C. Hill, and P. D. Cotter, "Bacteriocins: Novel solutions to age old spore-related problems?," Front. 
Microbiol., vol. 7, no. APR, 2016, doi: 10.3389/fmicb.2016.00461.

[22] C. Barcenilla, M. Ducic, M. López, M. Prieto, and A. Álvarez-Ordóñez, "Application of lactic acid bacteria for the biopreservation of meat products: A systematic review," Meat Sci., vol. 183, p. 108661, 2022, doi: 10.1016/j.meatsci.2021.108661.

[23] L. S. Fitria Ayuti and S. Iwaningsih, "Hubungan Pengetahuan, Sikap, Perilaku, Dan Standar Personal Higiene Penjamah Makanan Di Instalasi Gizi Rs Islam Jakarta Cempaka Putih," vol. 25, no. 2, pp. 69-75, 2018.

[24] F. Hereher, A. ElFallal, M. Abou-Dobara, E. Toson, and M. M. Abdelaziz, "Cultural optimization of a new exopolysaccharide producer 'Micrococcus roseus,", Beni-Suef Univ. J. Basic Appl. Sci., vol. 7, no. 4, pp. 632-639, 2018, doi: 10.1016/j.bjbas.2018.07.007.

[25] Z. tao Zhang, D. ying Zhang, K. Xie, C. jiang Wang, and $\mathrm{F}$. Xu, "Luteolin activates Tregs to promote IL10 expression and alleviating caspase-11-dependent pyroptosis in sepsis-induced lung injury," Int. Immunopharmacol., vol. 99, no. June, p. 107914, 2021, doi: 10.1016/j.intimp.2021.107914.

[26] L. Tian et al., "Luteolin as an adjuvant effectively enhances CTL anti-tumor response in B16F10 mouse model," Int. Immunopharmacol., vol. 94, no. January, p. 107441, 2021, doi: 10.1016/j.intimp.2021.107441.

[27] A. Setyawan, "Keragaman Varietas Jahe (Zingiber officinale Rosc.) berdasarkan Kandungan Kimia Minyak Atsiri," BioSMART J. Biol. Sci., vol. 4, no. 2, pp. 48-54, 2002, [Online]. Available: http://biosmart.mipa.uns.ac.id/index.php/biosmart/a rticle/view/104.

[28] N. Fazriyanti, "Lactic acid bacteria will consume reduced sugars as a carbon source for microbial metabolic activity.," Universitas Islam Negeri Maulana Malik Ibrahim Malang, 2015.

[29] P. Hidayati, Pujiati and Devi, "Pengaruh Konsentrasi Inokulum dan Lama Hidrolisis Bagasse oleh Aspergillus niger pada Proses Produksi Bioetanol," Proceeding Biol. Educ. Conf. Biol. Sci. Enviromental, Learn., vol. 13, no. 1, pp. 827-831, 2016, [Online]. Available: https://jurnal.uns.ac.id/prosbi/article/view/5928/53 14.

[30] S. Pacini and M. Ruggiero, "Description of a Novel Probiotic Concept: Implications for the Modulation of the Immune System," Am. J. Immunol., vol. 13, no. 2, pp. 107-113, 2017, doi: 10.3844/ajisp.2017.107.113. 